\title{
Biocidal polymers (II): Determination of Biological activity of novel $N$-halamine biocidal polymers and evaluation for use in water filters
}

\author{
A. E. I. Ahmed ${ }^{1}$, J. N. Hay ${ }^{1}$, M. E. Bushell ${ }^{2}$, J. N. Wardell ${ }^{2}$, G. Cavalli ${ }^{1}$ \\ ${ }^{I}$ Materials Chemistry Group, Chemical Sciences, Faculty of Health and Medical Sciences, University of \\ Surrey, Guildford, Surrey, UK. \\ ${ }^{2}$ Microbial Products Group, Microbial Sciences, Faculty of Health and Medical Sciences, University of \\ Surrey, Guildford, Surrey, UK.
}

Correspondence to: A. E.I.Ahmed ( a.i.ahmed@surrey.ac.uk)

\begin{abstract}
Novel $N$-Halamine biocidal polymers were prepared by co-polymerizing a heterocyclic ring-based monomer with tolylene-2,6-diisocyanate and toluene-2,4diisocyanate. The resulting polyurethanes were halogenated (chlorinated, brominated and iodinated). The rate of bacterial killing of the halogenated derivatives was determined with and without free halogen quenching and one of them was evaluated for use in water filters. The effect of these polymers on the bacterial growth-rate was also determined.
\end{abstract}

Key words: biocidal; polymer; $N$-Halamine; halogens; polyurethane; water filters.

\section{INTRODUCTION}

$N$-Halamine polymers are an important class of biocidal polymers. ${ }^{1-19}$ This type of polymer is prepared by introducing a heterocyclic ring containing amino, amide or imide groups into the polymer structure followed by halogenation to the corresponding $\mathrm{N}$ halamines, which confers on the polymer its biological activity. ${ }^{1-19}$ The biocidal activity is modulated by the halogen stability on the polymer, ${ }^{1-19}$ halogenated amines are more stable than amides and imides; ${ }^{18}$ in comparison, the halogenated imide exhibits the lowest stability but it gives the most powerful biocidal activity. ${ }^{18,19}$ In this work the prepared heterocyclic ring contains imide groups. The N-halogen bond has been stabilized by introducing electron donating groups on the ring; however, a high level of biocidal activity is still apparent. ${ }^{19}$ Halogen loading of these polymers was increased with respect 
to other examples in the literature by choosing a heterocyclic ring (uramil) (1) that can be charged with a maximum of 3 halogens per unit in comparison with 2 available positions in those similar polymers currently available, (scheme $1 \mathrm{~d}$ and e). ${ }^{1-18}$ Moreover, after polymerization the number of the available positions for halogenation increased to $5,{ }^{19}$ (scheme 2 and 3). We previously reported polymers prepared using uramil that showed good biological activity and good stability. ${ }^{19}$ These polymers were prepared by reacting polyacrylonitrile and polyethylacrylate with uramil (scheme $1 \mathrm{a}$ and $\mathrm{b}$ ) but the number of available positions for halogens was lower than the current polymers. In addition, a uramil-derived poly-urea was also prepared, ${ }^{19}$ (scheme $1 \mathrm{c}$ ), the number of positions available for halogen is 7 per repeating unit, and it will be evaluated in future work.

In this work we focus on a uramil-derived polyurethane (4) which was halogenated with $\mathrm{Cl}, \mathrm{Br}$ and I and the best choice selected for different applications (e.g., drinking water filters and sterilization). An analogous uramil-derived polyurethane (8) was chlorinated to compare its biological activity with the chlorinated form of (4). The bacterial killing rate of each halogenated derivative, both with and without free halogen quenching, was evaluated for cultures of Gram-positive (S. aureus) and Gram-negative bacteria (E. coli) bacteria. The effect of the non-halogenated polymer (4) on these bacteria was also examined.

\section{EXPERIMENTAL}

\section{Materials}

Barbituric acid, granulated tin, resorcinol, fuming nitric acid, sodium nitrite, toluene-2,4diisocyanate, tolylene-2,6-diisocyanate, bromine and iodine were supplied by Sigma Aldrich Chemicals, UK. Sodium hydroxide, hydrochloric acid, potassium permanganate, sulphuric acid, sodium thiosulfate and dimethylformamide were supplied by Fisher Chemicals, UK. Nutrient broth and Nutrient agar (Oxoid)

\section{Preparation of polymers}

The polymers under investigation were prepared according to the methodology reported earlier, ${ }^{19}$ as follows: 


\section{Diazotization of uramil}

Uramil $^{20}$ (1) (5-aminobarbituric acid) $(1.40 \mathrm{~g}, 0.01 \mathrm{~mol})$ was dissolved in $5 \mathrm{ml}$ concentrated sulphuric acid. The temperature was kept at $0^{\circ} \mathrm{C}$ using an external ice bath. A cold solution of $\mathrm{NaNO}_{2}\left[0.69 \mathrm{~g}\right.$ of $\mathrm{NaNO}_{2}(0.01 \mathrm{~mol})+10 \mathrm{ml}$ water $]$ was added dropwise to the uramil solution with stirring to form the uramil diazonium salt (2), ${ }^{19}$ Scheme (2).

\section{Preparation of 1,3-dihydroxy-4(5-azobarbituric acid)-benzene (3)}

Resorcinol (1.1 g, $0.01 \mathrm{~mol})$ and $\mathrm{NaOH}(5.5 \mathrm{~g}, 0.14 \mathrm{~mol})$ were dissolved in $20 \mathrm{ml}$ water and added gradually to cold uramil diazonium salt (2). The dark purple product that precipitated was filtered, washed copiously with cold water, dried and weighed, producing $2.6 \mathrm{~g}$ (99\% yield), Scheme (2). ${ }^{19}$

Analysis, FTIR (KBr): $v\left(\mathrm{~cm}^{-1}\right)$ 1603, 1705, 1411, 3100, 3432 and 2942. ${ }^{1} \mathrm{H}$ NMR (DMSO, $500 \mathrm{MHz}): \delta 1.3(\mathrm{~s}, 1 \mathrm{H}), 5.4(\mathrm{~s}, 1 \mathrm{H}), 6.2(\mathrm{~s}, 2 \mathrm{H}), 6.9-7.2(\mathrm{~s}, 3 \mathrm{H})$ and $10.2(\mathrm{~s}$, 1H). ${ }^{13} \mathrm{C}$ NMR (DMSO, $125 \mathrm{MHz}$ ): ppm 49, 102.4, 103, 105, 106, 129, 150.3 and 158.3. Elemental analysis, found (\%): C, 45.1; H, 2.9; N, 20.9. Calculated for $\mathrm{C}_{10} \mathrm{H}_{8} \mathrm{~N}_{4} \mathrm{O}_{5}(\%)$ : C, $45.5 ; \mathrm{H}, 3 ; \mathrm{N}, 21.2 .^{19}$

\section{General procedure for the polyurethane polymers (4) and (8)}

Monomer (3) (2.6 g, $0.01 \mathrm{~mol})$ and a suitable diisocyanate $(0.01 \mathrm{~mol})$ were heated in 30 $\mathrm{ml}$ dimethylformamide for 5 hours at $90^{\circ} \mathrm{C}$. The reaction was cooled and $50 \mathrm{ml}$ of methanol added. The brown product was filtered, washed copiously with methanol, dried and weighed, Scheme (3 and 4). ${ }^{19}$

Analysis of poly[(1,3-dihydroxy-4(5-azobarbituric acid)-benzene)-co-(tolylene-2,6diisocyanate)] (4), FTIR (KBr): $v\left(\mathrm{~cm}^{-1}\right)$ 1640, 1700, 1660, 3429, 1135, 1471 and 2920. ${ }^{1} \mathrm{H}$ NMR (DMSO, $\left.500 \mathrm{MHz}\right): \delta 2.2$ (s, 3H), 4.8 (s, 1H), $4.2(\mathrm{~s}, 1 \mathrm{H}), 6.8(\mathrm{~s}, 2 \mathrm{H}), 10.5$ (s, $1 \mathrm{H})$ and $7.0-8.4(\mathrm{~s}, 6 \mathrm{H}) .{ }^{13} \mathrm{C}$ NMR (DMSO, $\left.125 \mathrm{MHz}\right)$ : ppm 11.4, 49, 109.9, 111.6, $113.2,116117.9,118.5,120,121,125,137.3,137.7,146,150,185,163.0$ and 153.2. Elemental analysis, found (\%): C, 51.7; $\mathrm{H}, 3.2 ; \mathrm{N}, 18.1$. Calculated for $\mathrm{C}_{19} \mathrm{H}_{16} \mathrm{~N}_{8} \mathrm{O}_{7}(\%)$ : C, 52.1; H, 3.2; N, 19.2. ${ }^{19}$ 
Analysis of [1,3-dihydroxy-4(5-azobarbituric acid)benzene)-co-(tolulene-2,4diisocyanate)] (8), FTIR (KBr): $v\left(\mathrm{~cm}^{-1}\right)$ 1617, 1639, 1712, 3417, 3458, 3550, 1110, 1457. ${ }^{1} \mathrm{H}$ NMR (DMSO, $\left.500 \mathrm{MHz}\right): \delta 2.0(\mathrm{~s}, 3 \mathrm{H}), 6.4(\mathrm{~s}, 1 \mathrm{H}), 7.1(\mathrm{~s}, 1 \mathrm{H}), 6.9(\mathrm{~s}, 2 \mathrm{H}), 7.4$ - 8.5 (m, 6H), and 9.4 (s, 1H). ${ }^{13} \mathrm{C}$ NMR (DMSO, $125 \mathrm{MHz}$ ): ppm 12, 49, 106, 110, 113, $114,115,116,119,119.6,120,121,123,126,128,151,154$ and 160. Elemental analysis, found (\%): C, 51.8; $\mathrm{H}, 3.2 ; \mathrm{N}, 18.5$. Calculated for $\mathrm{C}_{19} \mathrm{H}_{16} \mathrm{~N}_{8} \mathrm{O}_{7}(\%)$ :, $52.1 ; \mathrm{H}, 3.2 ; \mathrm{N}$, $19.2 .^{19}$

\section{General Procedure for Halogenation}

The polymer was suspended in sodium hydroxide solution and the halogen (chlorine, bromine or iodine) was added gradually until neutralization to $\mathrm{pH}$ 7. The mixture was stirred for $1 \mathrm{~h}$ during which the temperature was kept below $5^{\circ} \mathrm{C}$ using an external ice bath. The resulting product was filtered, washed copiously with chlorine-free water, dried and weighed. ${ }^{19}$ The amounts of polymer and sodium hydroxide used in the preparation of each $N$-halamine polymer and the final yield are illustrated in Table 1.

\section{Effect of the halogenated polymers on the bacterial growth and viability}

A culture of E. coli was prepared by inoculating one bacterial colony into $20 \mathrm{ml}$ of nutrient broth in a Universal bottle and incubated for $24 \mathrm{hr}$ at $37^{\circ} \mathrm{C}$. From the bacterial suspension $0.1 \mathrm{ml}$ was transferred to a $20 \mathrm{ml}$ Universal bottle containing $10 \mathrm{ml}$ of new medium. A further five Universals were prepared so the total number was six; three used in testing the effect of the polymer on bacterial growth and the other three to test the effect of the polymer on the viability of the bacteria.

To study the effect of the polymer on the rate of growth of E. coli, $0.5 \mathrm{~g}$ of the halogenated polymer was added to the first bottle while $0.5 \mathrm{~g}$ from the control polymer (non-halogenated) was added to the second bottle to act as a polymer control and the third was left as a bacterial control without polymer. The three bottles were stirred at $37^{\circ} \mathrm{C}$ and sampled at timed intervals for viable count.

To study the effect of the polymer on the viability of E. coli, the other three bottles were incubated for $17 \mathrm{hr}$ at $37^{\circ} \mathrm{C}$, and the number of bacteria determined by viable count. Then $0.5 \mathrm{~g}$ of the halogenated polymer was added to one; $0.5 \mathrm{~g}$ of the control polymer (non- 
halogenated) was added to the second, to act as a polymer control and the third vessel was left as a bacterial control. The three bottles were stirred at room temperature. Samples from each culture were taken for viable count at regular time intervals, using the 'Miles and Misra technique'. ${ }^{21}$ A photo was taken of one of the plates from the counts, Figure 1.

The same procedure was repeated to test the effect of the halogenated polymers on a Gram-positive bacterium (S. aureus).

\section{Effect of the halogenated polymers on bacterial viability under free halogen quenching}

The previous experiment, studying the effect of the polymer on the bacterial viability, was repeated. During the viable counts $0.05 \mathrm{ml}$ of $0.5 \mathrm{M}$ sodium thiosulphate was added to each decimal dilution to quench any free halogen which can evolve during the reaction between the polymer and the bacteria.

\section{Effect of the non-halogenated polymer on the liquid medium}

Non-halogenated polymer, $0.5 \mathrm{~g}$, (non-halogenated 4) was added to each of two Universal bottles each containing $10 \mathrm{ml}$ of sterile liquid medium. One of these was stirred at ambient temperature and the other was stirred at $37^{\circ} \mathrm{C}$ for $17 \mathrm{hr}$.

The polymer was allowed to settle in each vessel and $5 \mathrm{ml}$ of the overlaying broth removed to a fresh, sterile, Universal bottle. Bacterial suspension, $0.05 \mathrm{ml}$, (either E. coli or $S$. aureus prepared as described above) was added to inoculate them and the growth of the cultures followed by viable count during incubation at $37^{\circ} \mathrm{C}$. Bacterial suspension, $0.05 \mathrm{ml}$, was used to inoculate $5 \mathrm{ml}$ of sterile liquid medium as a bacterial control and a viable count performed at the same time intervals as the incubated Universal bottles.

The retained polymer was examined by IR analysis for changes due to contact with the nutrient broth. 


\section{Determination of the amount of halogen released from the chlorinated polymer during contact with water, nutrient broth and bacterial medium}

Chlorinated polymer (5), $0.5 \mathrm{~g}$, was stirred with $10 \mathrm{ml}$ of chlorine-free water. The polymer was filtered, dried and the degree of halogenation of the polymer was determined before and after the experiment using iodometric titration in order to determine the amount of halogen released from the polymer to the water. ${ }^{10,19}$ The experiment was repeated using nutrient broth and bacterial suspensions (both E. coli and S. aureus) instead of chlorine-free water and in each case the amount of delivered halogen calculated.

\section{Evaluation of polymer (5) (chlorinated) in water column}

Polymer (5), $1.0 \mathrm{~g}$, was placed in a glass tube $(15 \mathrm{~cm}$ length and $1 \mathrm{~cm}$ diameter $)$ to a height of $4 \mathrm{~cm}$. Bacterial suspension [prepared by inoculating one bacterial colony in 20 $\mathrm{ml}$ of liquid medium (Nutrient Broth, Oxoid) and incubated for 17 hours at $37^{\circ} \mathrm{C}$ ] was passed through the column and the output from the column recycled through it again. Before recycling, $0.1 \mathrm{ml}$ from the passed liquid was sampled for viable count. Five cycles were performed for each column. Two columns contained the original polymer (nonchlorinated form of 5) which acts as a control, one for the S. aureus and the other for the E. coli. Two columns were made for the $\mathrm{N}$-halamine polymer (5), one for the S. aureus and the other for the E. coli, therefore four columns in total. The number of viable cells in the original bacterial suspensions was determined before passing the bacteria through the

column. ${ }^{3}$ The turbidity of the liquid before and after passing through the columns was also determined spectrophotometrically at $540 \mathrm{~nm} .{ }^{13-16}$ 


\section{RESULTS AND DISCUSSION}

The biological activity of a new synthesized N-halamine biocidal polymer as well as the mode of action of this type of polymers was evaluated. The effect of this N-halamine polymer on the bacterial growth was studied and one of its halogen derivatives was evaluated for use in water filters.

\section{Effect of the chlorinated polymer (5) on the bacterial growth-rate and viability}

1- Effect of polymer (5) on the growth rate of S. aureus and E. coli.

Figure 2 shows $S$. aureus does not grow in the presence of the chlorinated polymer (5) or in the presence of the polymer control; which, as it is not motile, may be due to adsorption of $S$. aureus onto the polymer surface. From Figure 4, it is shown that E. coli did not grow in the presence of the chlorinated polymer. However, unlike S. aureus it grew in the presence of the control polymer but at a different rate and to a lower final population than the E. coli bacterial control. This may be due to differences in the motility and surface composition of the two types of bacteria.

2- Effect of polymer (5) on the viability of S. aureus and E. coli.

From Figure 3, it can be seen that a $3 \log$ reduction in the bacterial population was achieved with the chlorinated polymer (5) in $7 \mathrm{~min}$ while no bacterial colonies were detected after 15 minutes (equivalent to a $9 \log$ reduction) in the case of S. aureus. From Figure 5, a $3 \log$ reduction in the bacterial population was achieved with the chlorinated polymer (5) in 7 min while no colonies were detected after 15 minutes (equivalent to a 10 $\log$ reduction) in the case of $E$. coli.

As shown in Figures 2 and 4 the non-halogenated polymer (4) inhibits the growth of $S$. aureus and has some limited effect on the growth of E. coli. A plausible explanation may be the removal of critical nutrient broth components by the polymer through adsorption on its surface. To investigate this possibility we treated fresh broth with polymer (4) at different temperatures, removed the polymer by allowing it to settle, removing and using the overlying liquor, and inoculated the isolated medium with a fresh culture of S. aureus. 
The bacterial growth was followed by viable counts at different times. These results are shown in Figures 6 and 7.

Figures 6 and 7 show that treating the broth with non-halogenated polymer (4) adversely affects the rate of bacterial growth even after removal of the polymer, although to a lesser extent than when the polymer is still present. This suggests that there may be a dual mode of action, one by direct contact polymer-bacteria (possibly there is a large extent of bacterial adsorption in the case of $S$. aureus) and another by affecting the broth composition (through nutrient adsorption on the polymer).

\section{Effect of the brominated polymer (6) on growth and viability of E. coli and S. aureus}

1- Effect of the brominated polymer (6) on E. coli and S. aureus growth rate.

The results show there was no growth of E. coli in the presence of the brominated polymer, (Figure 8), and no growth of $S$. aureus was detected in the presence of the brominated polymer or in presence of the polymer control, (Figure 10).

2- Effect of the brominated polymer (6) on E. coli and S. aureus viability.

A $3 \log$ reduction in the bacterial population was achieved with the brominated polymer in $7 \mathrm{~min}$ and no bacterial growth was detected after $15 \mathrm{~min}$ (equivalent to a $9 \log$ reduction) in case of E. coli, (Figure 9). Similarly, a $3 \log$ reduction in the population of $S$. aureus was achieved with the brominated polymer (6) in $7 \mathrm{~min}$ and no viable bacteria were detected after 15 min (equivalent to $9 \log$ reduction), (Figure 11).

\section{Studying the effect of iodinated polymer (7) on the bacterial growth and viability of}

\section{E. coli and S. aureus}

1- Effect of the iodinated polymer (7) on E. coli and S. aureus growth.

No growth of E. coli was detected in the presence of the iodinated polymer (7). A reduction in the population was also observed in the polymer control (PC) compared to the bacterial control (BC). Similarly, no growth of $S$. aureus was detected in the presence of the iodinated polymer (7) or in the presence of the control polymer, (Figure 12 and 14). 
2- Effect of the iodinated polymer (7) on E. coli and S. aureus viability.

Figure 13 shows a $10 \log$ reduction in the population of E. coli was observed after $7 \mathrm{~min}$ following contact between the polymer and the bacteria. Staph aureus behaves similarly; no colonies were detected after 7 min contact between the iodinated polymer (7) and the bacteria (Figure 15). To determine the rate of killing of the iodinated polymer, the same experiment was repeated but using $0.25 \mathrm{~g}$ of the polymer in contact with $10 \mathrm{ml}$ of bacterial suspension and the interval times were reduced to detect any viable bacterial colonies early in the culture.

For E. coli, a $5 \log$ reduction in the bacterial population was achieved in $1 \mathrm{~min}$ and no viable colonies detected (equivalent to $10 \log$ reduction) after $5 \mathrm{~min}$ contact time. The results for $S$. aureus were unequivocal, the rate of killing of by the iodinated polymer could not be determined due to the powerful effect of the polymer; no viable colonies were detected after 1 min contact time (equivalent to $9 \log$ reduction), (Figure 16 and 17).

\section{Killing rate determination with free halogen quenching}

The mechanism of killing using halogenated polymers can occur through release of soluble halogen species from the polymer or by contact between bacteria and the halogenated polymer, or both. To investigate this, we studied the rate of killing of halogenated polymers in the presence of a free-halogen quencher (sodium thiosulphate).

\section{1- Chlorinated polymer (5)}

The chlorinated polymer achieved a $2 \log$ reduction in the E. coli population in $40 \mathrm{~min}$ and no viable colonies were detected after $1.5 \mathrm{hr}$ (9 $\log$ reduction). Similarly the chlorinated polymer achieved a $1 \log$ reduction in $40 \mathrm{~min}$ for the $S$. aureus population and no bacterial colonies were detected in $1.5 \mathrm{hr}$ (9 log reduction), Figures 18 and 19.

\section{2- Brominated polymer (6)}

The brominated polymer achieved a $4 \log$ reduction in the E. coli population in $40 \mathrm{~min}$ and no viable colonies were detected after $1.5 \mathrm{hr}(9 \log$ reduction) while it achieved a 4 $\log$ reduction in the $S$. aureus population in $15 \mathrm{~min}$ and no viable colonies were detected after $40 \mathrm{~min}$ (9 $\log$ reduction), Figure 20 and 21. 


\section{3- Iodinated polymer (7).}

The experiment was performed by $1 \mathrm{~g}: 40 \mathrm{ml}$ ratio between the polymer weight and the bacterial suspensions because of the high power of the iodinated polymer. In spite of decreasing the polymer amount no E. coli or S. aureus colonies were detected at $7 \mathrm{~min}(9$ $\log$ reduction), Figures 22 and 23.

From the previous results (Figures 2-19) it was clear that the most powerful biocidal polymer is the iodinated polymer which shows the greatest biological effect. The rate of killing of the chlorinated and brominated polymers are very similar without halogen quenching, while with halogen quenching, the brominated polymer shows a powerful effect on each type of bacteria. This is may be related to the stability of the halogen on the polymer; I-N bonds have the lowest stability therefore the halogen can be exchanged easily between the polymer and bacteria. The $\mathrm{Cl}-\mathrm{N}$ exhibits the lowest biological power but is the most stable bond; hence its use in water filters. The difference in the killing rate of the polymer with and without the halogen quenching indicates that there is free halogen species (released from the polymers) involved in the biocidal action. However, some biocidal activity is retained in the presence of the quenching agent which suggests some biocidal effect depends on the action of the halogenated polymer itself and proceeds through contact between bacteria and polymer particles. ${ }^{1-18}$ This dual mechanism of killing (contact + release of halogen species) is currently under investigation and will be reported in due course. In addition to these two expected modes of action there is another possibility: killing the bacteria by changing the nature of the environment around the bacterial cells by exchanging the halogen between the halogenated polymer and proteins in medium. This last possibility can be explained by calculating the amount of released halogen in different media, Table 2.

\section{Amount of released chlorine}

To confirm the presence of free halogen species released from the polymer, the amount of delivered chlorine from the polymer to the bacteria was determined by iodometric titration of the halogenated polymer isolated after controlled contact with water, broth medium and the bacterial suspensions, (Table 2). 
From table 2, the amount of delivered chlorine to water is very low but increased for Nutrient broth medium, possibly through chlorine exchange between the polymer and protein in the broth medium, which supports the possibility of bacterial death due to changing the nature of the nutrient in the medium, in addition to the release effect and a contact effect.

In the presence of bacteria the amount of delivered chlorine increased indicating that more free chlorine is released from the polymer when in contact with bacteria. The mechanism or the mode of action of this process is under further investigation.

\section{Determination of the killing rate of the chlorinated polymer (9) under quenching conditions and in comparison with another chlorinated polymer (5)}

This experiment was performed to investigate the suitability of using the alternative commercial, but low purity, toluene-2,4-diisocyante instead of tolylene-2,6-diisocyante. From Figure 24, chlorinated polymer (9) achieved a $6 \log$ reduction of the E. coli population in $40 \mathrm{~min}$ and no bacterial colonies were detected after $40 \mathrm{~min}$ (equivalent to $9 \log$ reduction). For S. aureus, (Figure 25) the chlorinated polymer (9) achieved a $6 \log$ reduction in $40 \mathrm{~min}$ and no colonies were detected after $90 \mathrm{~min}$ (equivalent to $9 \log$ reduction). From Figures 24 and 25 it was clear that using toluene-2,4-diisocyanate (polymer 9) instead of tolylene-2,6-diisocyante (polymer 5) gave very close results.

\section{Chlorinated polymer (5) evaluation in water filters.}

This experiment investigated the potential to use one of these halogenated polymers in water filters on a laboratory scale.

a) Figures 26 and 27 show the effect of the control polymer (4) contained in $4 \mathrm{~cm}$ length $\mathrm{X} 1 \mathrm{~cm}$ diameter column on $S$. aureus and E. coli respectively.

From Figure 26, no $S$. aureus cells were detected in the eluate from the first column whereas in Figure 27, the control polymer (4) shows some filtration effect on E. coli but not as much as for S. aureus.

A spectrophotometric study was performed on the broth passed through the control column. The absorbance was measured before perfusing the column and after the fifth 
cycle. The broth after the fifth cycle was collected and incubated for $24 \mathrm{hr}$ and the absorbance measured again. Viable counts were also performed, Table 3. From these it is clear that, $S$. aureus bacterial cells were removed more efficiently than for $E$. coli but the system has not sterilized the water, as bacterial growth can be detected after further incubation, suggesting that control polymer (4) is acting as a filter but not exerting biocidal action.

b) Results from columns containing the chlorinated polymer $\mathbf{5}$ are shown in figures 28 , 29 and table 4 :

The chlorinated polymer (5) succeeded in reducing the viable count after the first cycle for both Gram-positive and Gram-negative bacteria.

As previously, a spectrophotometric study was performed (Table 4) and it is clear that, for both types of bacteria, the turbidity decreased to very low values. A bleaching effect was also observed in the broth medium, resulting in negative values after 5 cycles. After the 24 hours further incubation no bacterial growth was detected, indicating that the chlorinated polymer had succeeded in killing the heavy bacterial loading demonstrating the potential application of this polymer in water filters.

\section{CONCLUSIONS}

The rate of bacterial killing of new prepared polymers was examined and the effect of these polymers on bacterial growth determined. Iodinated polymer showed greater biocidal power than chlorinated and brominated polymers. Investigations performed with and without free-halogen quenching indicate that there is a difference in killing-rate suggesting that the mode of action of these polymers is dual; proceeding through both release of free halogen species into the medium and through bacteria-polymer contact. In addition, a third possibility exists of changing the nature of nutrients around the bacteria by interaction between the halogenated polymer and medium proteins. The nonhalogenated polymer also showed an inhibitory effect on growth of $S$. aureus. One of the prepared N-halamine polymers (5) (chlorinated) was used successfully in a laboratory column for sterilizing a bacterial culture. 


\section{ACKNOLDGMENT}

The project is sponsored by the Egyptian government.

\section{REFERENCES AND NOTES}

1- Sun, G.; Wheatly, W.B.; Worley, S.D. Ind Eng Chem Res 1994, 33, 168.

2- Sun, G.; Allen, L.C.; Luckie, E.P.; Wheatly, W.B.; Worley, S.D. Ind Eng Chem Res 1994, 34, 4106.

3- Sun, G; Chen, T.Y.; Wheatly, W.B.; Worley, S.D. J Bioact Compat Polym 1995, 10, 135.

4- Sun, G.; Chen, T.Y.; Habercom, M.S; Wheatly, W.B.; Worley, S.D. J Am Water Res Assoc 1996, 32, 793.

5- Panangala, V.S.; Liu, L.; Sun, G.; Worley, S.D; Mitra, A. J Virol Meth 1997, 66, 263.

6- Chen, Y.; Worley, S.D.; Kim, J.; Wei, C.-I; Chen, T.Y. Ind Eng Chem Res 2003, 42, 280.

7- Chen, Y; Worley, S.D.; Kim, J.; Wei, C.-I; Suess, J. Chem Res 2003, 42, 5715.

8- Chen, Y.; Worley, S.D.; Huang, T.S.; Weese, J.; Kim, J.; Wei, C.-I J Appl Polym Sci 2004, 92, 363.

9- Chen, Y.; Worley, S.D.; Huang, T.S.; Weese, J.; kim, J.; Wei, C.-I J Appl Polym Sci 2004, 92, 368 .

10- Chen, Z.; Sun, Y. Ind Eng Chem Res 2006, 45, 2634.

11- Liang, J.; Owens, J. R.; Huang, T. S.; Worley, S. D. J Appl Polym Sci 2006, 101, 5.

12- Worley, S.D.; Williams,D.E. Crit Rev Environ Cont 1988, 18, 133.

13- El-Masry A.M. Pigment and Resin Tech2005, 34, 265.

14- Moustafa, H.Y. Pigment \& Resin Tech 2006, 35, 71.

15- El-Masry, A.M.; Moustafa, H.Y.; Ahmed, A.I.; Shaaban, A.F. Pigment \& Resin Tech $2004,33,75$.

16- El-Masry, A.M.; Moustafa, H.Y.; Ahmed, A.I.; Shaaban, A.F. Pigment \& Resin Tech 2004, 33, 211.

17- Barnes, K.; Liang, J.; Wu, R.; Worley, S.D.; Lee, J.; Broughton, R.M.; Huang, T.S. Biomaterials 2006, 27, 4825.

18- Chen, Z.; Luo, J.; Sun, Y. Biomaterials 2007, 28, 1597. 
19- Ahmed, A.E.I.; Hay, J.N.; Bushell, M.E.; Wardell, J.N.; Cavalli, G. Reactive and Functional Polymers (in press).

20- Brian, S.F.; Antony, J.H.; Peter, W.G.S.; Austin, R.T. 'Vogel' text book of practical organic chemistry’ Longman Ltd Fifth edition 1989.

21- Miles A.A.; Misra S.S. Journal of Hygiene (London) 1938, 38, 732. 
Figure 1. Example on the viable counts using the Miles and Misra method.

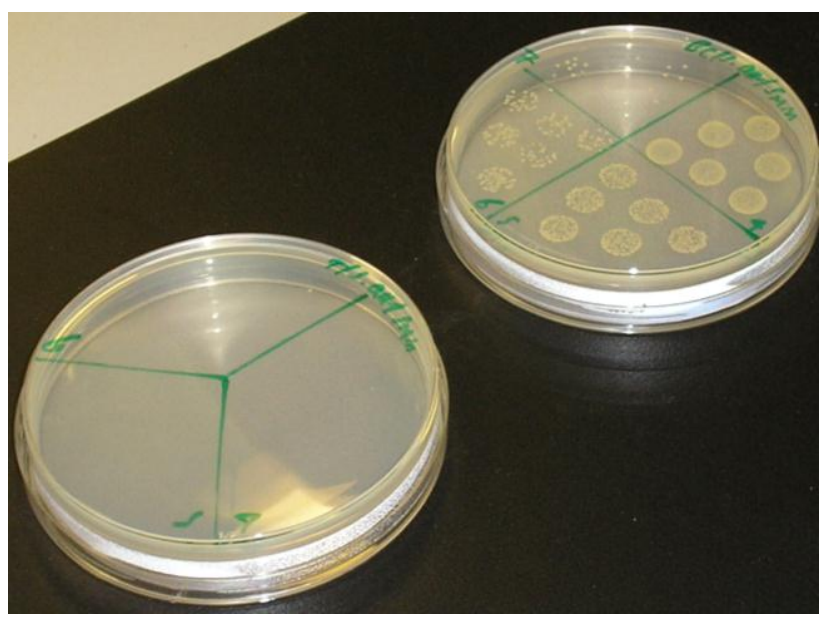




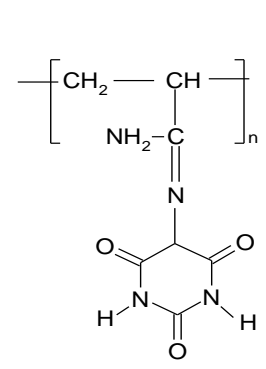

(a)

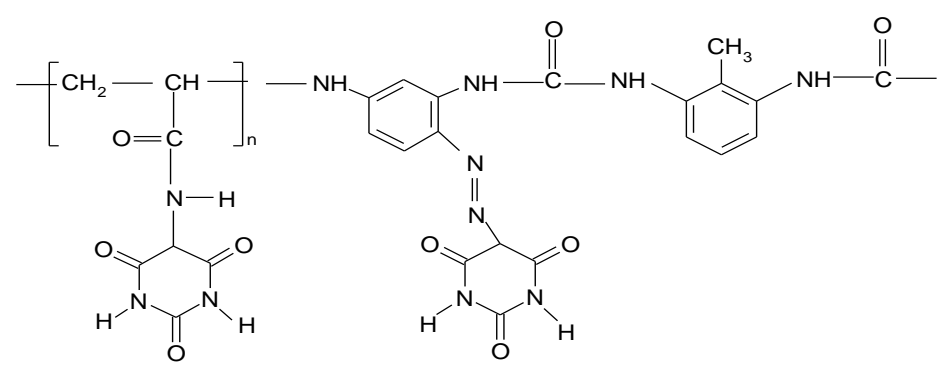

(b)

(c)

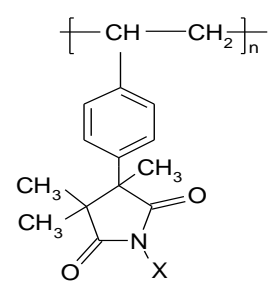

(d)

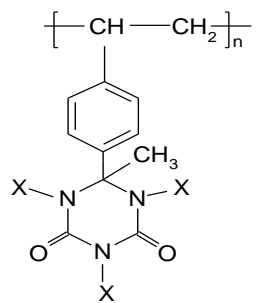

(e)

Scheme 1. Different types of N-halamine biocidal polymer. 


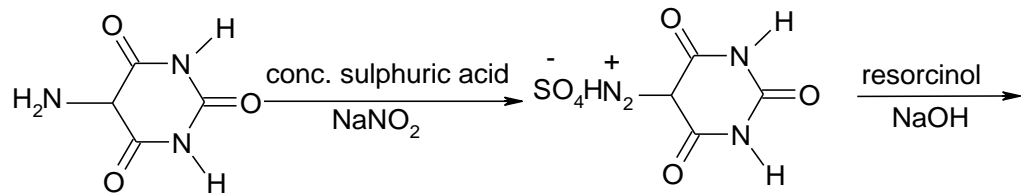

(1)

Uramil (5-aminobarbituric acid)
(2)

5-barbituro diazonium sulphate

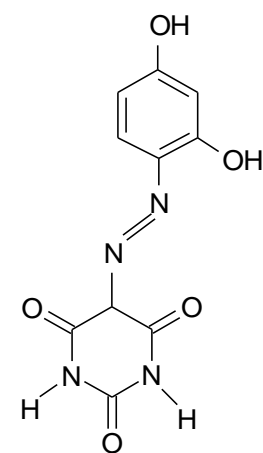

(3)

Scheme 2. Diazotization of uramil and its coupling with resorcinol. 


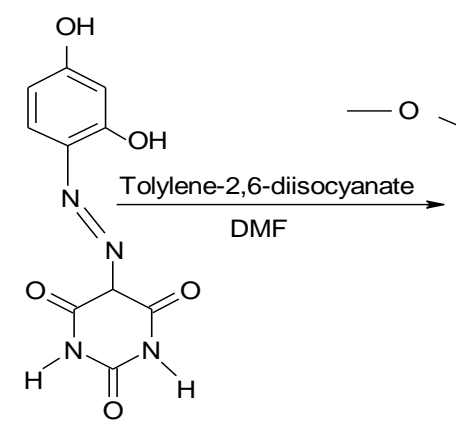

(3)
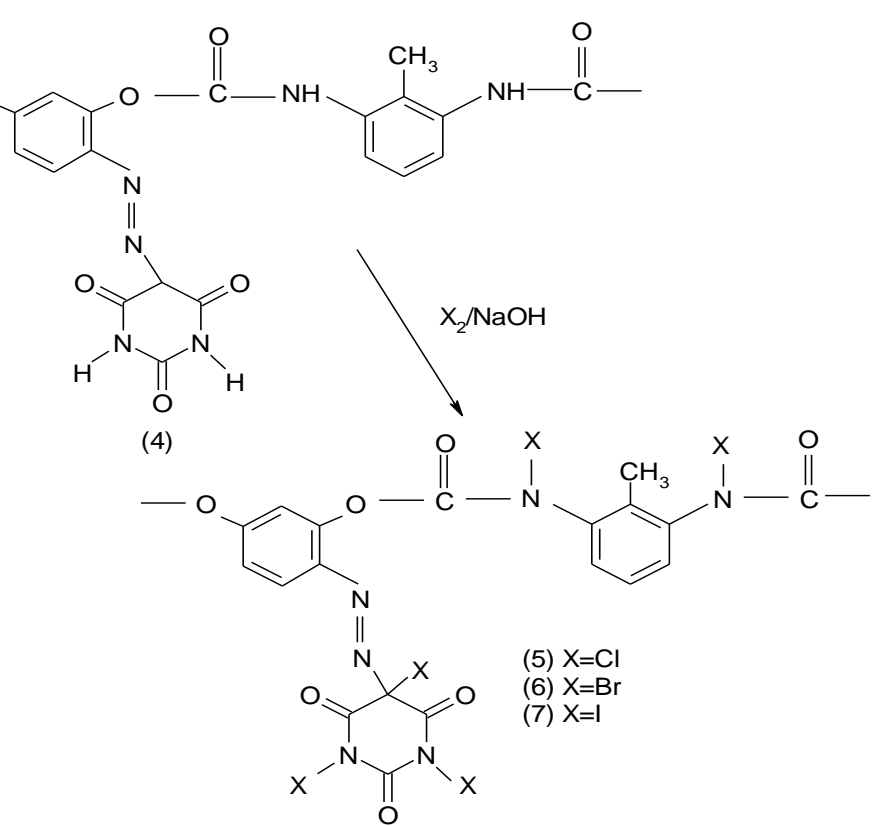

Scheme 3. Preparation of poly[(1,3-dihydroxy-4(5-azobarbituric acid)-benzene)-co(tolylene-2,6-diisocyanate)] (polyurethane 4) and its halogenation. 


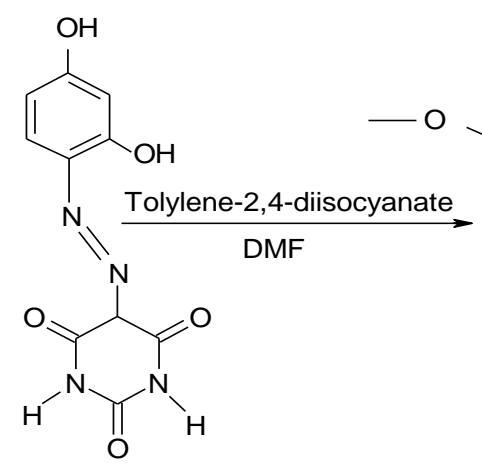

(3)
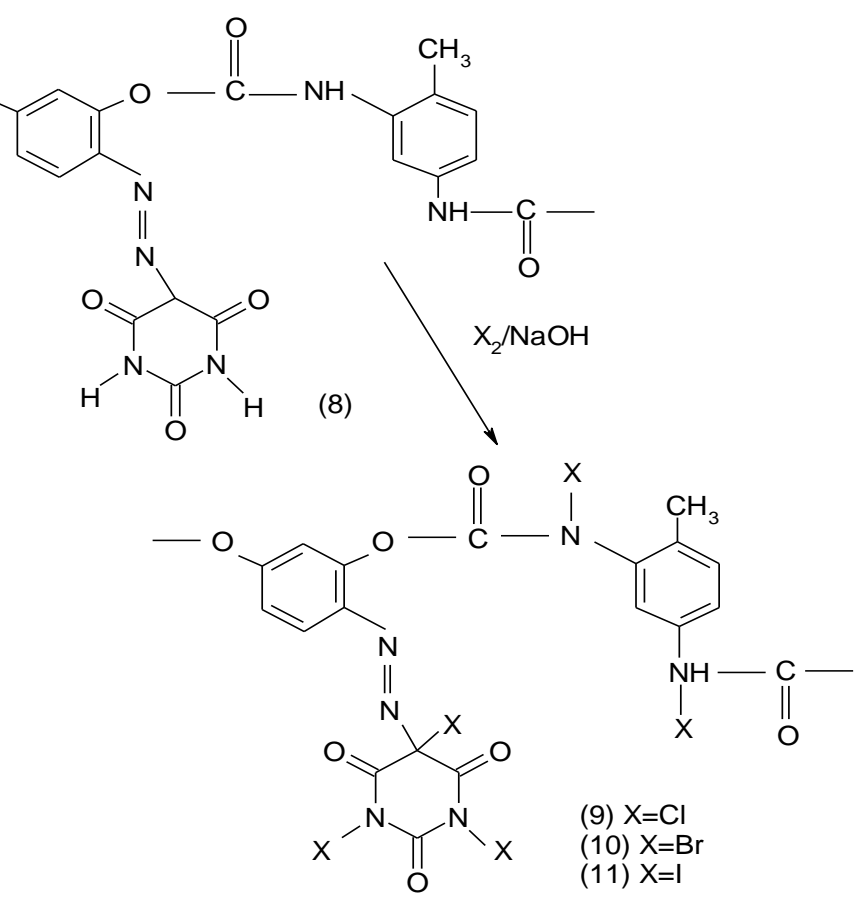

Scheme 4. Preparation of poly[(1,3-dihydroxy-4(5-azobarbituric acid)-benzene)-co(tolylene-2,4-diisocyanate)] (polyurethane 8) and its halogenation. 
Table 1. Amounts of polymer and sodium hydroxide used in the preparation of the $\mathrm{N}$ halamine polymers and the final yields

\begin{tabular}{|l|c|c|c|}
\hline \multicolumn{1}{|c|}{ Product. } & $\begin{array}{c}\text { Reactant (weight, } \\
\text { quantity }) .\end{array}$ & $\begin{array}{c}\text { Sodium hydroxide } \\
(\mathrm{g})\end{array}$ & Final yield \\
\hline $\mathbf{5}$ (chlorinated) & $\mathbf{4}(0.44 \mathrm{~g}, 0.001 \mathrm{~mol})$ & $0.20(0.005 \mathrm{~mol})$ & $0.4 \mathrm{~g}(66 \%)$ \\
\hline 6 (brominated) & $\mathbf{4}(0.44 \mathrm{~g}, 0.001 \mathrm{~mol})$ & $0.20(0.005 \mathrm{~mol})$ & $0.6 \mathrm{~g}(67 \%)$ \\
\hline $\mathbf{7}$ (iodinated) & $\mathbf{4}(0.44 \mathrm{~g}, 0.001 \mathrm{~mol})$ & $0.20(0.005 \mathrm{~mol})$ & $0.7 \mathrm{~g}(64 \%)$ \\
\hline $\mathbf{9}$ (chlorinated) & $\mathbf{8}(0.44 \mathrm{~g}, 0.001 \mathrm{~mol})$ & $0.20(0.005 \mathrm{~mol})$ & $0.5 \mathrm{~g}(82 \%)$ \\
\hline
\end{tabular}


Table 2. The amount of delivered chlorine from the chlorinated polymer (1g:20ml):

\begin{tabular}{|c|c|}
\hline & Amount of released chlorine $^{\mathrm{a}}$ \\
\hline water & $0.19 \mathrm{ppm} \pm 0.05$ \\
\hline broth medium & $3.9 \mathrm{ppm} \pm 0.12$ \\
\hline E. coli $\left(1.7 \times 10^{9} \mathrm{cfu} / \mathrm{ml}\right)+$ broth medium & $8.5 \mathrm{ppm} \pm 0.32$ \\
\hline S. aureus $\left(3.1 \times 10^{8} \mathrm{cfu} / \mathrm{ml}\right)+$ broth medium & $5.9 \mathrm{ppm} \pm 0.24$ \\
\hline
\end{tabular}

(1 $\mathrm{g}: 20 \mathrm{ml})$ is the ratio between the weight of polymer and the liquid.

Note: ${ }^{a}$ Determined as difference between original chlorine content in the polymer and chlorine content after contact with the different media. 
Table 3. Absorbance values (at wavelength 540nm) before and after perfusing the column, read against a nutrient broth blank:

\begin{tabular}{|l|l|l|}
\hline & E. coli & S. aureus \\
\hline Before perfusing the column & 0.41 & 0.3 \\
\hline After the fifth cycle & 0.3 & 0.04 \\
\hline After incubating the fifth cycle for $24 \mathrm{hr}$ & 1.33 & 0.46 \\
\hline The counts of the incubating fifth cycle. & $2.5 \times 10^{9} \mathrm{cfu} / \mathrm{ml}$ & $7.5 \times 10^{7} \mathrm{cfu} / \mathrm{ml}$ \\
\hline
\end{tabular}


Table 4. Absorbance values (at wavelength $540 \mathrm{~nm}$ ) before and after perfusing the column, read against a nutrient broth blank.

\begin{tabular}{|l|l|l|}
\hline & E. coli & S. aureus \\
\hline Before perfusing the column & 0.27 & 0.323 \\
\hline After the fifth cycle & -0.018 & -0.009 \\
\hline After incubating the fifth cycle for $24 \mathrm{hr}$ & 0.001 & 0.03 \\
\hline The counts of the incubating fifth cycle. & $\mathrm{Nd}$ & $\mathrm{Nd}$ \\
\hline
\end{tabular}


Figure 2. Log plot of viable counts of $S$. aureus grown in the presence of the chlorinated polymer (5), the control polymer and bacterial control.

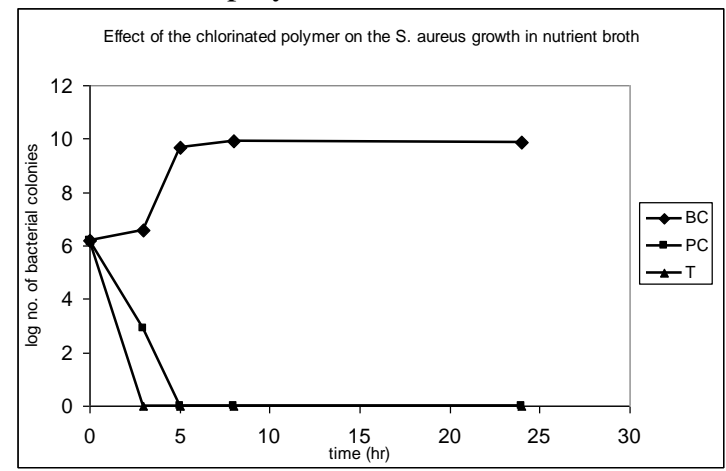

Note: T: $\log$ no. of colonies for the chlorinated test polymer, PC: $\log$ no. of colonies for the control polymer, BC: $\log$ no. of colonies of the bacterial control.

Figure 4. Log plot of viable counts of E. coli growth in the presence of the chlorinated polymer, control polymer and a bacterial control.

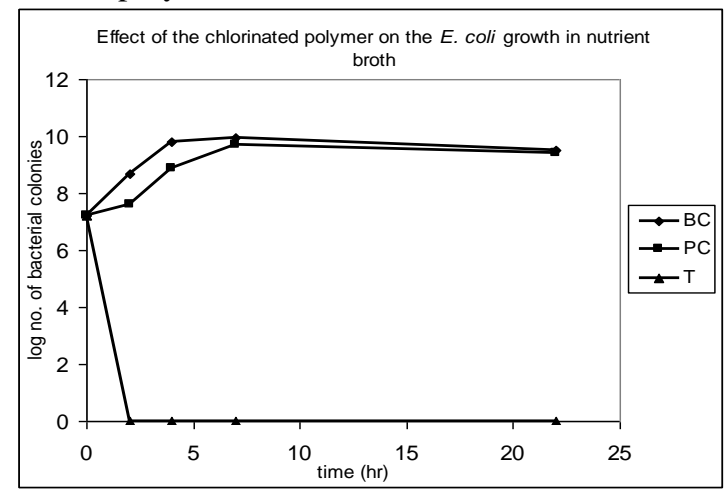

Where: $\mathrm{T}$ is the $\log$ no. of colonies for the chlorinated polymer, $\mathrm{PC}$ is the $\log$ no. of colonies for the control polymer and $\mathrm{BC}$ is the $\log$ no. of colonies of the bacterial control.
Figure 3. Log plot of viable counts of S. aureus in nutrient broth after contact with the chlorinated polymer, control polymer and bacterial control.

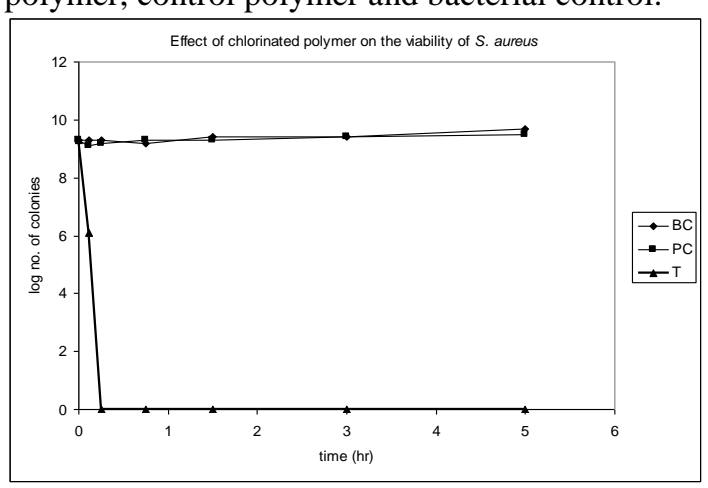

Note: $\mathrm{T}$ is the $\log$ no. of colonies for the chlorinated polymer, $\mathrm{PC}$ is the $\log$ no. of colonies for the control polymer and $\mathrm{BC}$ is the log no. of colonies of the bacterial control. PC and BC are superimposed

Figure 5. Log plot of viable count of E. coli after contact with the chlorinated polymer, control polymer and bacterial control.

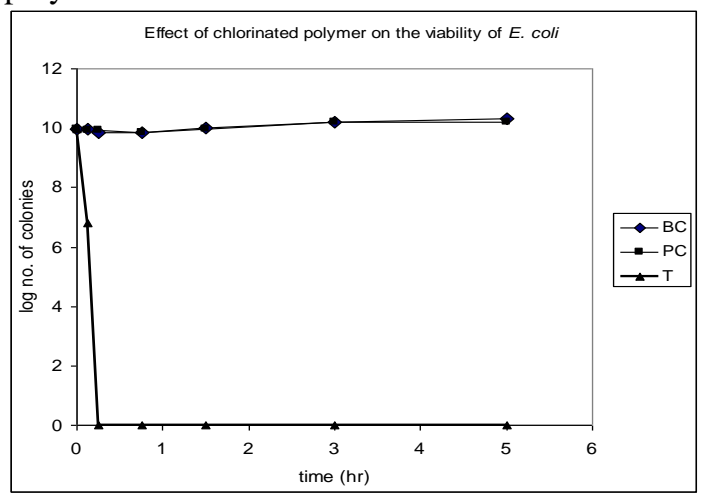

Where: $\mathrm{T}$ is the $\log$ no. of colonies for the chlorinated polymer, $\mathrm{PC}$ is the $\log$ no. of colonies for the control polymer and $\mathrm{BC}$ is the $\log$ no. of colonies of the bacterial control. PC and BC are superimposed. 


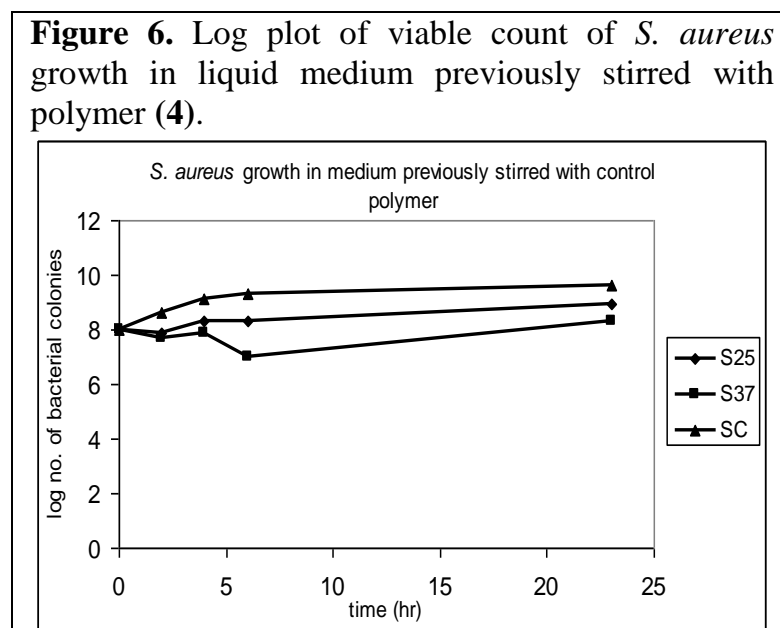

Where: $S_{37}$ is the $\log$ no. of $S$. aureus colonies incubated at $37^{\circ} \mathrm{C} . \mathrm{S}_{25}$ is the $\log$ no. of $S$. aureus colonies incubated at $25^{\circ} \mathrm{C} . \mathrm{S}_{\mathrm{c}}$ is the $\log$ no. of $S$. aureus colonies for the bacterial control grown in fresh nutrient broth incubated at $37^{\circ} \mathrm{C}$.
Figure 7. Log plot of viable count of E. coli grown in liquid Nutrient broth medium previously stirred with the control polymer (4).

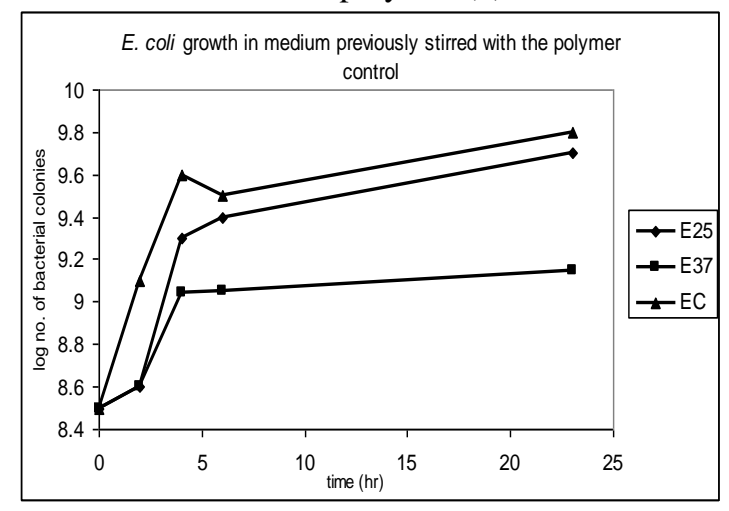

Where: $\mathrm{E}_{25}$ is the $\log$ no. of $E$. coli colonies for the bacteria incubated at $25^{\circ} \mathrm{C} . \mathrm{E}_{37}$ is the $\log$ no. of $E$. coli colonies for the bacteria incubated at $37^{\circ} \mathrm{C}$. $\mathrm{E}_{\mathrm{C}}$ is the $\log$ no. of $E$. coli colonies for the bacteria in fresh nutrient broth at $37^{\circ} \mathrm{C}$. 


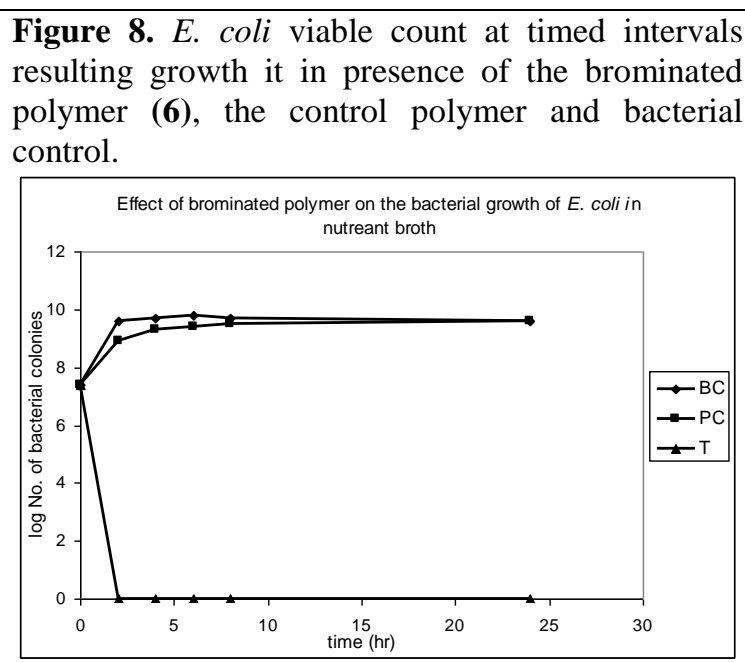

Where: $\mathrm{T}$ is the no. of colonies $(\mathrm{cfu} / \mathrm{ml})$ for the brominated polymer, $\mathrm{PC}$ is the no. of colonies $(\mathrm{cfu} / \mathrm{ml})$ for the control polymer and $\mathrm{BC}$ is the no. of colonies $(\mathrm{cfu} / \mathrm{ml})$ of the bacterial control.

Figure 10. $S$. aureus viable count at timed intervals resulting growing in presence of the brominated polymer (6), bacterial control and the polymer control.

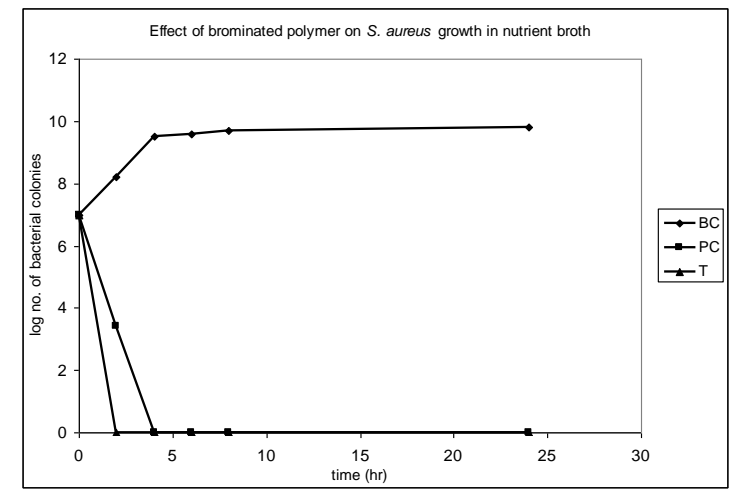

Where: $\mathrm{T}$ is the no. of colonies $(\mathrm{cfu} / \mathrm{ml})$ for the brominated test polymer, $\mathrm{PC}$ is the no. of colonies $(\mathrm{cfu} / \mathrm{ml})$ for the control polymer and $\mathrm{BC}$ is the no. of colonies $(\mathrm{cfu} / \mathrm{ml})$ of the bacterial control PC and $\mathrm{T}$ are superimposed.
Figure 9. Log no. of colonies at timed intervals after contact between the brominated polymer (6) and $E$. coli in Nutrient broth.

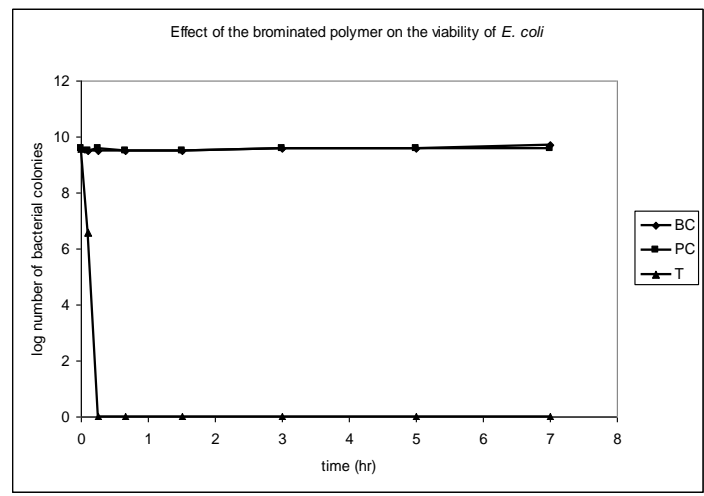

Where: $\mathrm{T}$ is the $\log$ no. of colonies for the brominated polymer, $\mathrm{PC}$ is the $\log$ no. of colonies for the control polymer and $\mathrm{BC}$ is the $\log$ no. of colonies of the bacterial control. BC and PC are superimposed.

Figure 11. Log no. of $S$. aureus colonies at timed intervals after contact with the brominated polymer (6), the polymer control and bacterial control.

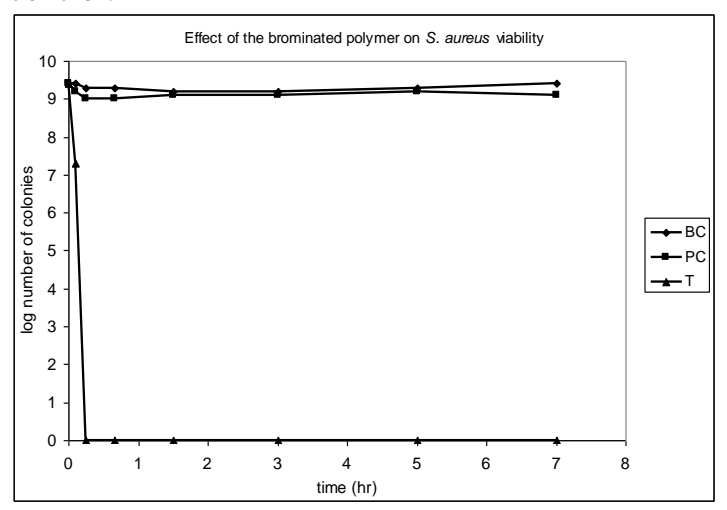

Where: $\mathrm{T}$ is the $\log$ no. of colonies for the brominated polymer, $\mathrm{PC}$ is the $\log$ no. of colonies for the control polymer and $\mathrm{BC}$ is the $\log$ no. of colonies of the bacterial control. 
Figure 12. $E$. coli viable count at timed intervals during growth in nutrient broth in the presence of the iodinated polymer (7), the polymer control and bacterial control.

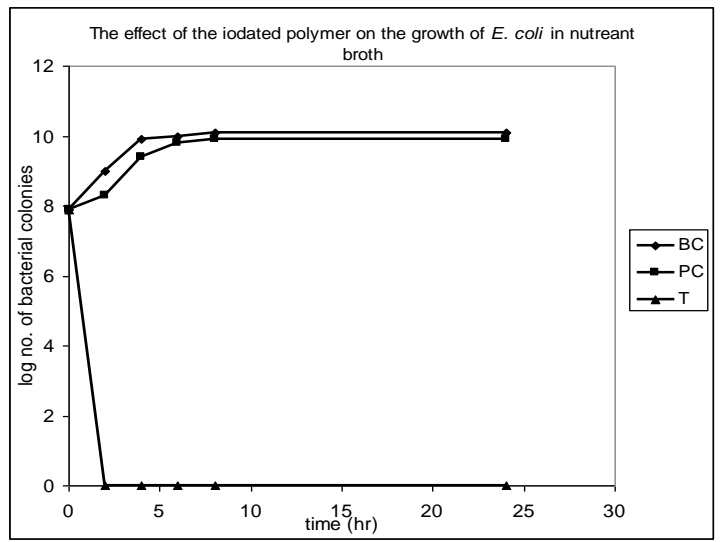

Where: $\mathrm{T}$ is the no. of colonies $(\mathrm{cfu} / \mathrm{ml})$ for the iodinated polymer, $\mathrm{PC}$ is the no. of colonies $(\mathrm{cfu} / \mathrm{ml})$ for the control polymer and $\mathrm{BC}$ is the no. of colonies $(\mathrm{cfu} / \mathrm{ml})$ of the bacterial control.

Figure 14. S. aureus viable count at timed intervals after growth in nutrient broth in the presence of the iodinated polymer (7), the polymer control and bacterial control.

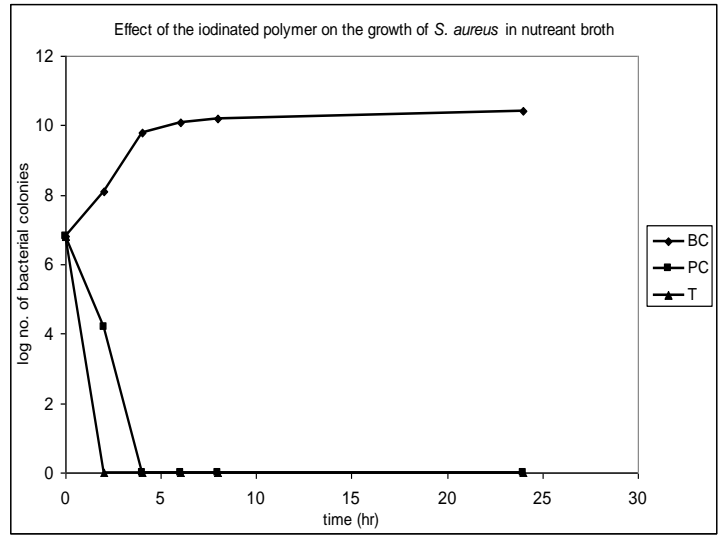

Where: $\mathrm{T}$ is the no. of colonies $(\mathrm{cfu} / \mathrm{ml})$ for the iodinated polymer, $\mathrm{PC}$ is the no. of colonies $(\mathrm{cfu} / \mathrm{ml})$ for the control polymer and $\mathrm{BC}$ is the no. of colonies $(\mathrm{cfu} / \mathrm{ml})$ of the bacterial control. PC and $\mathrm{T}$ are superimposed.
Figure 13. Log no. of bacterial colonies at timed intervals after contact between the iodinated polymer (7) and E. coli compared to polymer control and bacterial control.

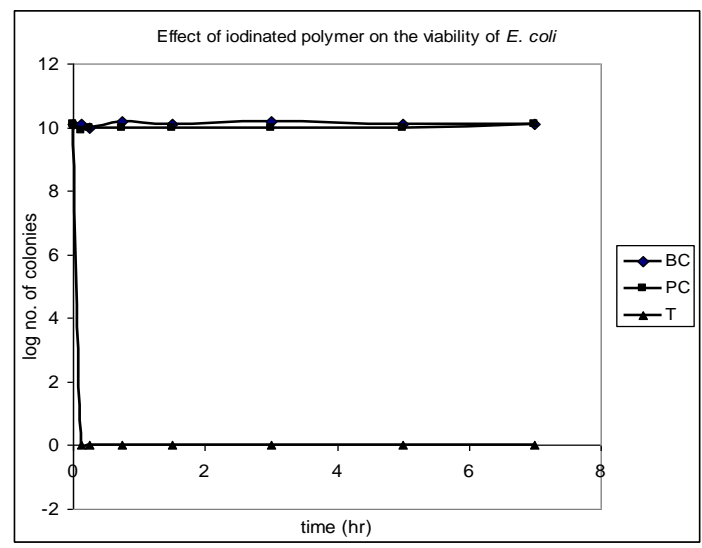

Where: $\mathrm{T}$ is the $\log$ no. of colonies for the iodinated polymer, $\mathrm{PC}$ is the $\log$ no. of colonies for the control polymer and $\mathrm{BC}$ is the $\log$ no. of colonies of the bacterial control.

Figure 15. Log no. of the bacterial colonies at timed intervals after contact between $S$. aureus and iodinated polymer (7), a bacterial control and the polymer control.

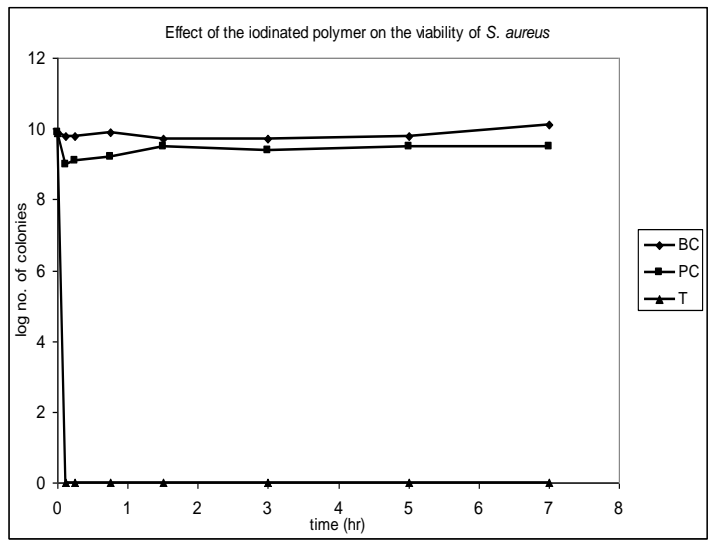

Where: $\mathrm{T}$ is the $\log$ no. of colonies for the iodinated polymer, $\mathrm{PC}$ is the $\log$ no. of colonies for the control polymer and $\mathrm{BC}$ is the $\log$ no. of colonies of the bacterial control. 


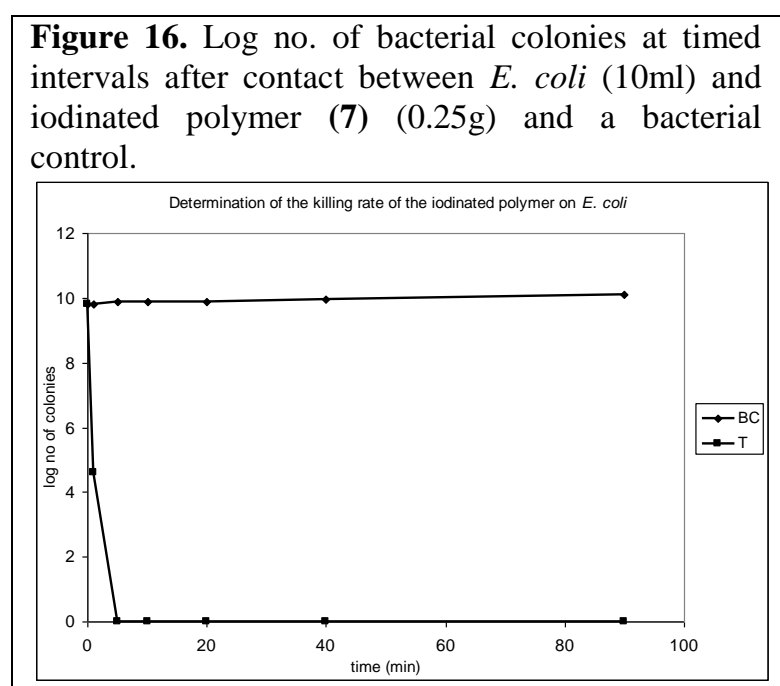

Where: $\mathrm{T}$ is the $\log$ no. of colonies for the iodinated polymer and $\mathrm{BC}$ is the $\log$ no. of colonies of the bacterial control.
Figure 17. Log no. of the bacterial colonies at timed intervals after contact between iodinated polymer (7) $(0.25 \mathrm{~g})$ and $S$. aureus $(10 \mathrm{ml})$ compared to a bacterial control.

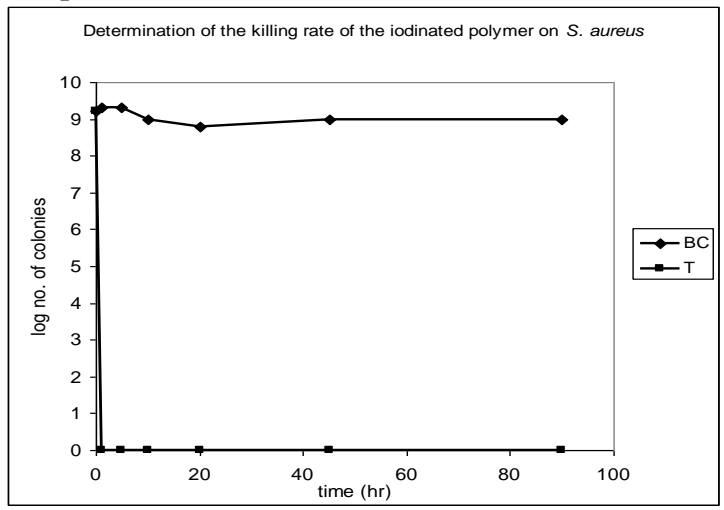

Where: $\mathrm{T}$ is the $\log$ no. of colonies for the iodinated polymer and $\mathrm{BC}$ is the $\log$ no. of colonies of the bacterial control. 
Figure 18. Effect of the chlorinated polymer (5) on the viability of $E$. coli under chlorine quenching.

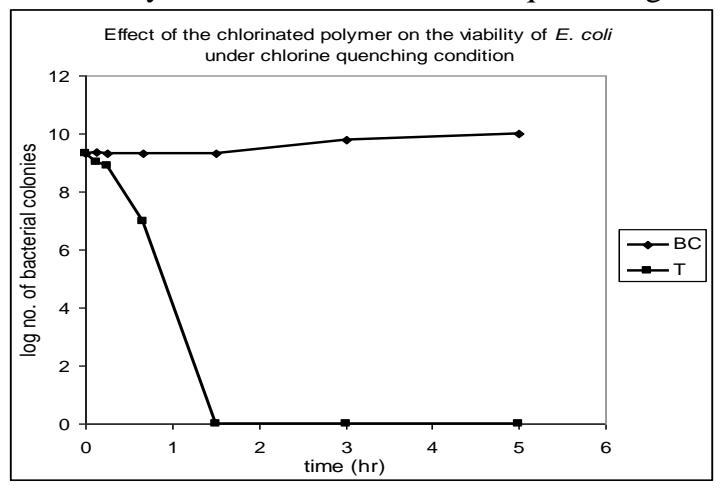

Where: $\mathrm{T}$ is the $\log$ no. of colonies for the chlorinated polymer and $\mathrm{BC}$ is the $\log$ no. of colonies of the bacterial control.

Figure 20. Effect of the brominated polymer (6) on E. coli viability under chlorine quenching.

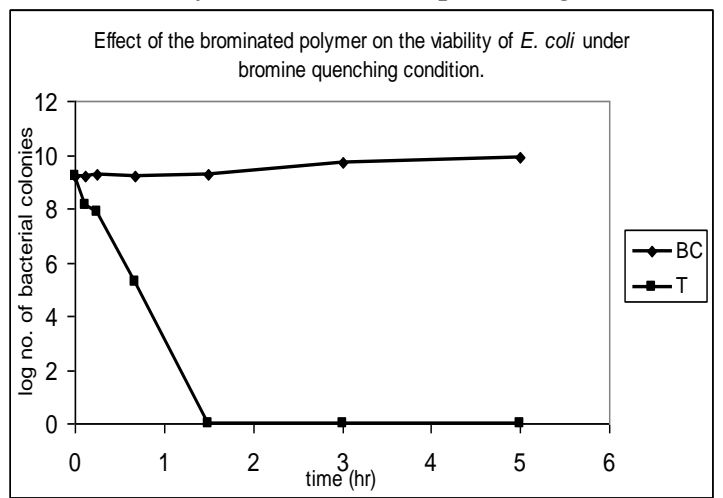

Where: $\mathrm{T}$ is the $\log$ no. of colonies for the brominated polymer and $\mathrm{BC}$ is the $\log$ no. of colonies of the bacterial control

Figure 22. Effect of the iodinated polymer (7) on $E$. coli viability under chlorine quenching.

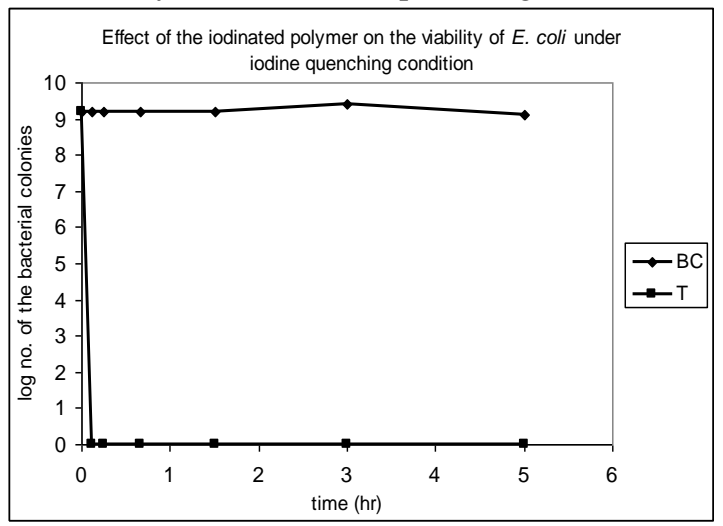

Where: $\mathrm{T}$ is the $\log$ no. of colonies for the iodinated polymer and $\mathrm{BC}$ is the $\log$ no. of colonies of the bacterial control.
Figure 19. Effect of the chlorinated polymer (5) on $S$. aureus viability under chlorine quenching.

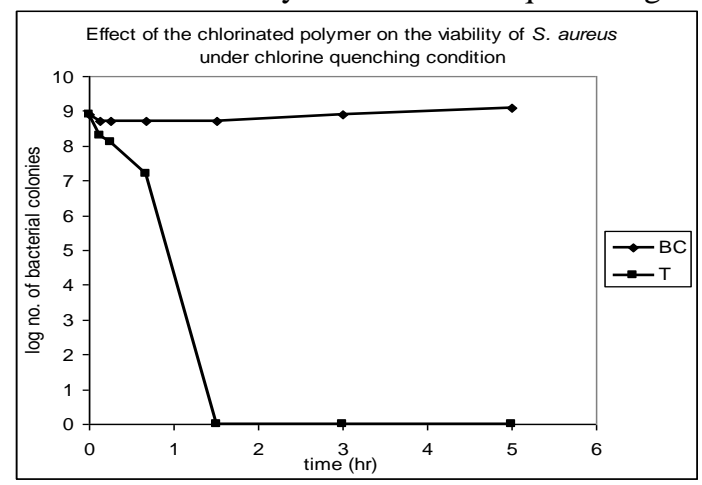

Where: $\mathrm{T}$ is the $\log$ no. of colonies for the chlorinated polymer and $\mathrm{BC}$ is the $\log$ no. of colonies of the bacterial control.

Figure 21. Effect of the brominated polymer (6) on $S$. aureus viability under chlorine quenching.

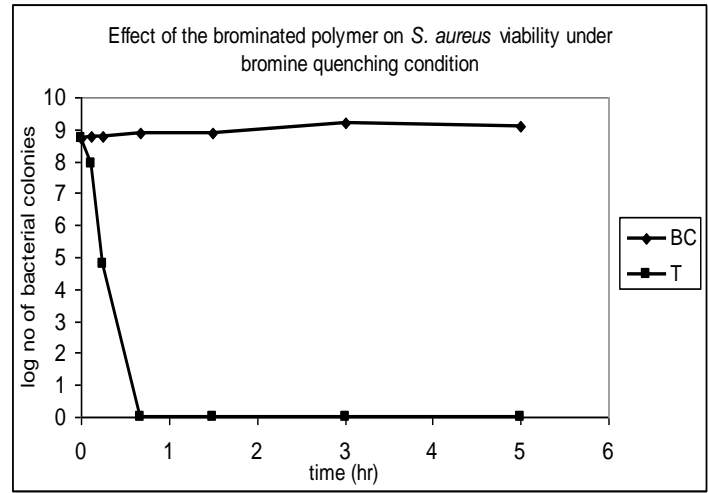

Where: $\mathrm{T}$ is the $\log$ no. of colonies for the brominated polymer and $\mathrm{BC}$ is the log no. of colonies of the bacterial control.

Figure 23. Effect of the iodinated polymer (7) on S.aureus viability under chlorine quenching.

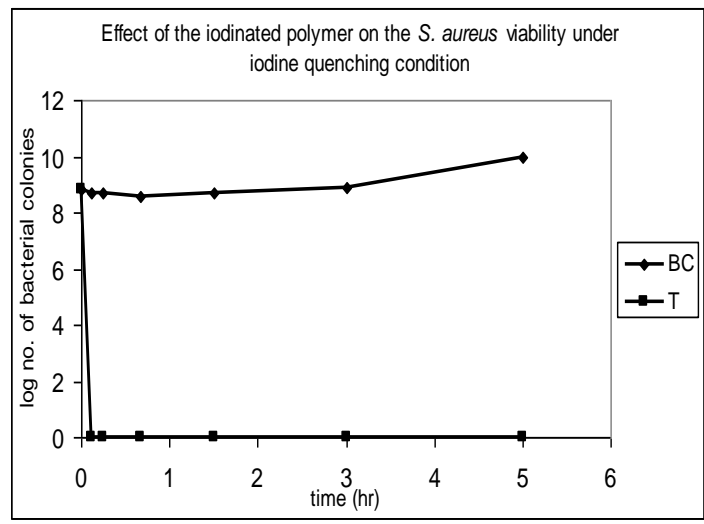

Where: $\mathrm{T}$ is the $\log$ no. of colonies for the iodinated polymer and $\mathrm{BC}$ is the $\log$ no. of colonies of the bacterial control 
Figure 24. Effect of chlorinated polymer (9) on the viability of $E$. coli under chlorine quenching.

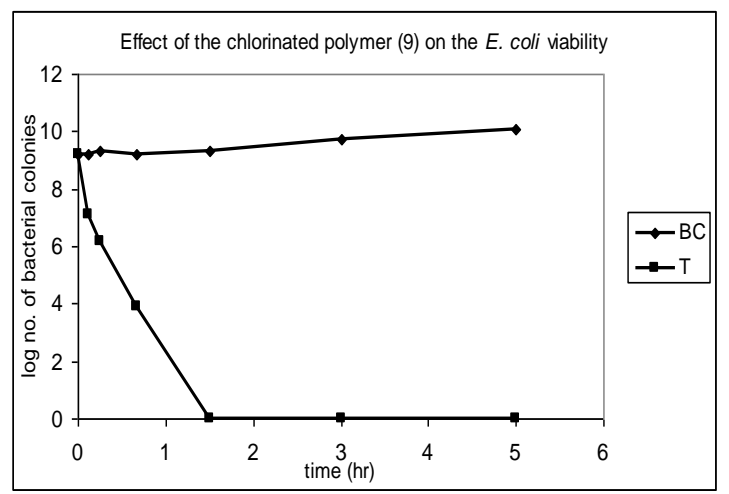

Where: $\mathrm{T}$ is the $\log$ no. of colonies for the chlorinated polymer and $\mathrm{BC}$ is the $\log$ no. of colonies of the bacterial control.
Figure 25. Effect of chlorinated polymer (9) on the viability of $S$. aureus under chlorine quenching.

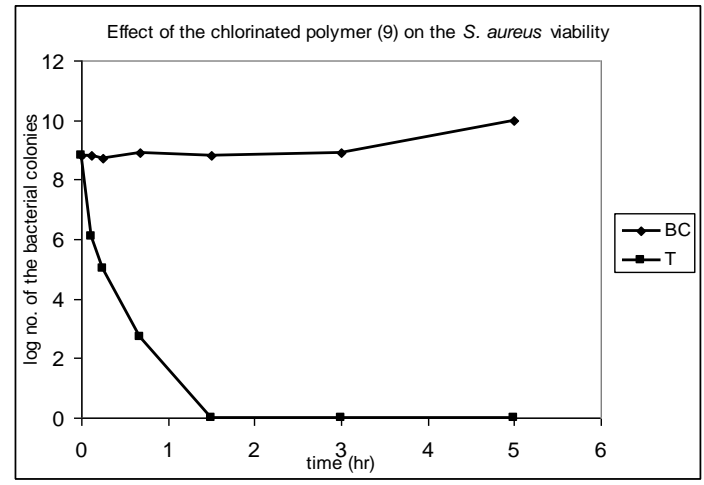

Where: $\mathrm{T}$ is the $\log$ no. of colonies for the chlorinated polymer and $\mathrm{BC}$ is the $\log$ no. of colonies of the bacterial control 


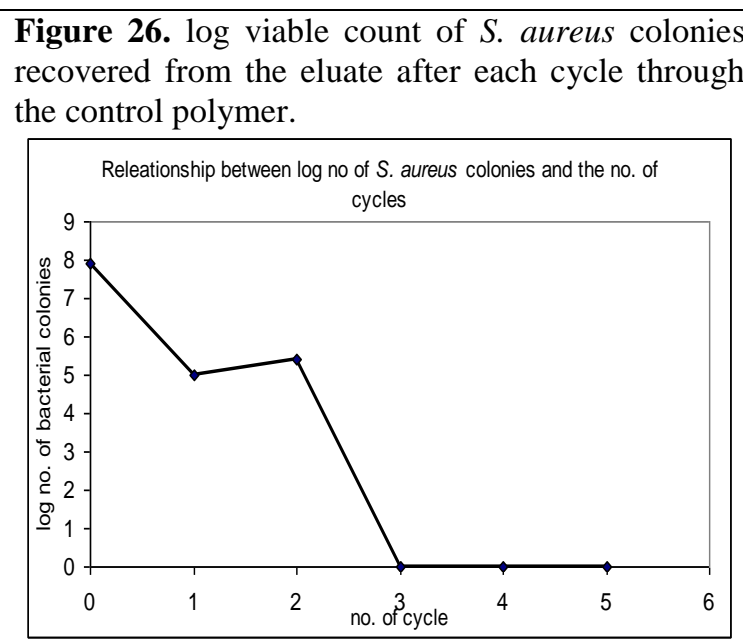

Figure 28. $S$. aureus $\log$ viable counts after each cycle through the chlorinated polymer column.

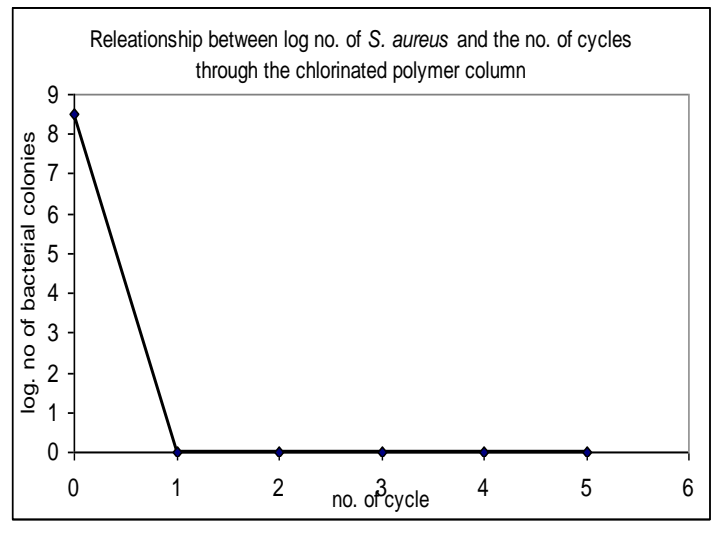

Figure 27. $\log$ viable count of E. coli recovered from the eluate after each cycle through the control polymer.

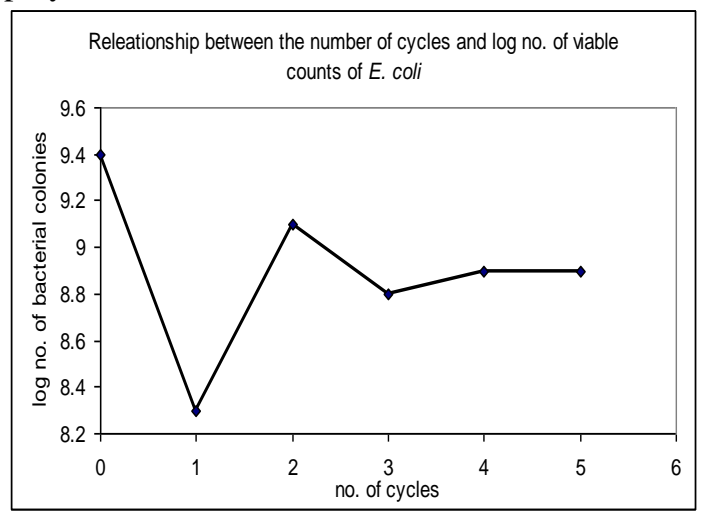

Figure 29. E. coli $\log$ viable counts after each cycle through the chlorinated polymer column.

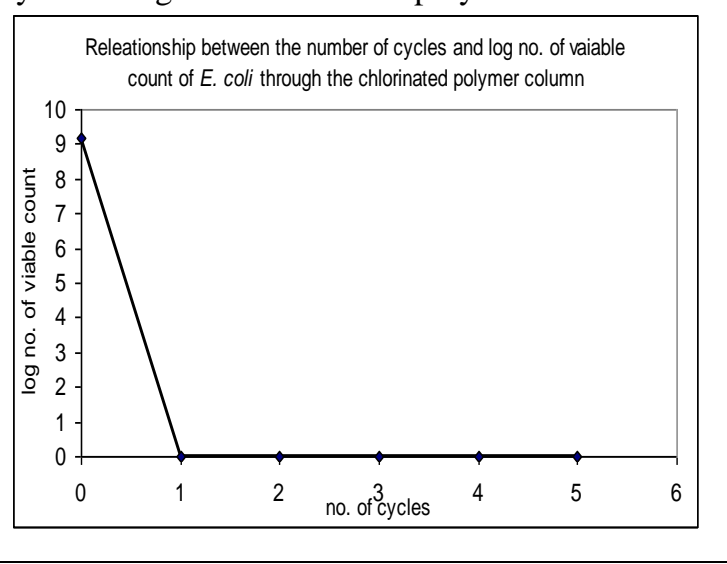

